Wojciech Ligęza

Uniwersytet Jagielloński

wligeza@wp.pl

\title{
Herbert: krótka historia czytania
}

\section{Herbert: The Short History of Reading}

Abstract: In this paper the author examines the problems of reception of the Zbigniew Herbert's poems and essays - from the first collection of poems entitled Struna swiatta to the latest writings of the reviewers and scholars. The reflections devoted to the "Herbertian" studies take into consideration various styles of reading, aesthetic preferences, axiology, applied methods of research, and ways of interpretation. The history of reading of the Herbert's works is presented in the chronological, thematic and problem order. Discussed are the most important monographic books, studies and essays, which address the extensive range of issues, reveal a broad spectrum of styles and methods of reading, illustrate the long process of getting to know the Herbert's work, and finally prove the great popularity of this creative work. From interpretation of several poems we pass to the attempts at generalization, from existential and metaphysic meanings - to the cultural reading. The library of texts devoted to the Herbert's creative work is not a closed collection as new articles and books still appear, and the search for the "new Herbert" is supported by the new humanistic languages.

Keywords: Herbert's creative works, literary reception, styles of reading, history of Polish criticism, interpretation, methodology, new literatures

Streszczenie: W szkicu podjęte zostają zagadnienia recepcji twórczości poetyckiej oraz eseistycznej Zbigniewa Herberta - od debiutanckiego zbioru Struna światta do najnowszych wypowiedzi badaczy i krytyków. Refleksja poświęcona studiom herbertologicznym uwzględnia zmienne style odbioru, preferencje estetyczne oraz ideowe, aksjologię, stosowane metody badawcze oraz klucze interpretacji. Historia czytania utworów Herberta przedstawiona zostaje w porządku chronologicznym, tematycznym oraz problemowym. Przedmiotem rozważań stają się najważniejsze książki monograficzne, studia i szkice, które ukazują rozbudowany zakres zagadnień, pozwalają dostrzec szeroką skalę stylów i sposobów lektury, ilustrują długi proces poznawania utworów Herberta, a wreszcie uświadamiają, jak wielka jest popularność tego dzieła. Od interpretacji poszczególnych wierszy przechodzimy do prób uogólnień, od wykładni egzystencjalnych i metafizycznych do czytania kulturowego. Biblioteka tekstów o Herbercie nie jest kolekcją zamkniętą, wciąż bowiem dołączają kolejne rozpoznania, a poszukiwania „nowego Herberta” wspierane są przez nowe języki humanistyczne.

Słowa kluczowe: twórczość Herberta, recepcja, style lektury, historia polskiej krytyki, interpretacja, metodologia, nowe literaturoznawstwo 


\section{Różne wizerunki poezji i poety}

Liczba tekstów o Herbercie przyrasta w sposób tak żywiołowy, że nawet literaturoznawcy-specjaliście trudno zapanować nad bibliografią tego fascynującego, skomplikowanego myślowo i artystycznie przedmiotu ${ }^{1}$. „Herbertologia” znacznie się oddaliła od punktów wyjścia, rozwinęła i przekształciła w wyspecjalizowaną domenę refleksji. Wypowiedzi o tym znakomitym poecie, eseiście, dramaturgu, epistolografie dotyczą kwestii coraz bardziej szczegółowych. Kolejne poznawcze tendencje i zainteresowania humanistyczne wymieniających się pokoleń badaczy zostają nałożone na pisarstwo Herberta, ale też w tej twórczości partytury znaczeń skłaniają do nowych odczytań.

Ze wszech miar ciekawe zjawisko popularności pisarstwa Zbigniewa Herberta zasługuje na uważną analizę. Bez wdawania się w niuanse można jedynie wspomnieć o tym, że poeta wzbogacił rozumienie dawnych cywilizacji i kultur, rozwinął literacką refleksję o sztuce, od malowideł w Lascaux, poprzez malarstwo wczesnego renesansu włoskiego, po ulubionych Holendrów z XVII wieku, odnowił podróżopisarstwo, rozmyślał o mechanizmach dziejów, wskazał nowe możliwości w zakresie poetyckiego filozofowania. Herbert wyznaczył drogi literatury współczucia i wierności, stał się wzorem „postawy wyprostowanej" w czasach totalitarnej opresji, był przenikliwym diagnostą kryzysu człowieczeństwa, poetycko badał naturę bytu, unikając deklaracji religijnych, wykazywał odniesienia życia ludzkiego do transcendencji, sięgał po dykcję elegijną, wreszcie - głęboko wypowiadał się o cierpieniu, umieraniu, śmierci. To, co związane było ze zbiorowym losem, odnosił do wartości uniwersalnych. Zmienił właściwie romantyczny wzór charyzmatycznego przywódcy, gdyż, jak pisze Barbara Toruńczyk, Herbert: „Pragnął może polski patriotyzm tradycyjny i katolicki o romantycznej proweniencji wyposażyć w cnoty antyczne i osadzić w perspektywie cywilizacji europejskiej"2.

Pytania o poezję, dramaturgię oraz eseistykę Herberta muszą również uwzględniać zmienne gusty literaturoznawców, krytyków, miłośników artystycznego słowa, a także fluktuacje upodobań estetycznych, nastawień filozoficznych oraz miar wartości. Zatem w tych komentarzach wydaje się niezbędna kategoria doświadczenia - po stronie pisarza i po stronie odbiorców.

${ }^{1}$ Ta praca nawiązuje do wcześniejszego szkicu - rozwiniętego, uzupełnionego o najnowsze prace dotyczące twórczości Herberta: W. Ligęza, Nieustanne komentowanie. Wokót recepcji Zbigniewa Herberta w Polsce [w:] Herbert Środkowoeuropejczyk. Twórczość Zbigniewa Herberta w kontekstach i kontaktach środkowoeuropejskich, red. K. Krasuski, Katowice 2011, s. 100-149. Zagadnieniom obioru poświęcony został także tom zbiorowy Herbert na językach. Wspótczesna recepcja twórczości Zbigniewa Herberta $w$ Polsce i na świecie, red. A. Grabowski, J. Kopciński, J. Snopek, Warszawa 2010. Zob. też S. Barańczak, Nieporozumienia [w:] tegoż, Uciekinier z Utopii. O poezji Zbigniewa Herberta, Londyn 1984, s. 5-29.

2 B. Toruńczyk, Dukt pisma, dukt pamięci, „Zeszyty Literackie” 1999 nr 4, s. 178, przedruk [w:] Poznawanie Herberta 2, red. A. Franaszek, Kraków 2000, s. 74-81. 
Sposoby czytania szybko się wyczerpują, zużywają, petryfikują, przeto rozwijająca się w czasie lektura wydobywa inne wymiary tego pisarstwa. Aleksander Fiut rozpoczyna swój szkic znamiennym zdaniem: „Krytycznoliteracki portret Zbigniewa Herberta zmienia się jak na obrotowej scenie"3. Wraz ze zmianami historycznymi, społecznymi, kulturowymi odzwierciedlonymi w pismach krytyków - przedstawicieli kolejnych pokolen - następuje więc poszukiwanie „nowego Herberta”.

To oczywiste, że autor Elegii na odejście inaczej był czytany w PRL-u, kiedy Polacy, uwięzieni w zgrzebnej rzeczywistości, za pośrednictwem literatury pragnęli zastępczo przeżywać sen śródziemnomorski, inaczej w czasach solidarnościowej odnowy i stanu wojennego, kiedy wiersze Herberta traktowano jak katechizm czy też skład zasad dla wspólnoty, a jeszcze inaczej po odzyskaniu wolności i zmianie paradygmatu kultury. Przynajmniej chwilowo możliwe było umieszczenie tej twórczości poza polityką, oczywiście jeśli wyłączymy teksty publicystyczne, i wydobycie w wierszach Herberta tematyki osobistych rozliczeń z życiem oraz cierpieniem.

W trwającej ponad sześć dekad recepcji czytelnicy (i krytycy) znajdowali w przybliżanej twórczości to, co odpowiadało potrzebom chwili. Style i sposoby lektury odchodziły więc w przeszłość. Na przykład traktowanie poety jako trybuna moralnej rewolucji, z pomijaniem ironii i dystansu, okazało się koniec końców nieporozumieniem ${ }^{4}$. Zapewne w czytaniu ideologicznym, patriotycznym i wolnościowym, kiedy oczekiwano prawd niezbitych i prostych, nie zostały dostrzeżone czynniki sprzeczności oraz ironii, na co najwyraźniej wskazuje społeczne przyswojenie Przestania Pana Cogito 5 . Po 1989 roku deszyfrowanie języka ezopowego straciło atrakcyjność, nastąpiły przesunięcia w preferencjach lekturowych, a wieszcza antykomunizmu w nowym wcieleniu zastąpił poeta egzystencjalny i metafizyczny, zgłębiający tajemnice istnienia, wrażliwy na cierpienie, zakładający możliwość spotkania z sacrum, analizujący niedogodności ludzkiego losu. W ostatnim tomie, w Epilogu burzy, utrwalił się wizerunek artysty słowa, podejmującego odważnie temat ars moriendi, poety lamentu oraz dzielności.

W tym szkicu z konieczności ograniczam się głównie do recepcji dokonań poetyckich Zbigniewa Herberta, podejmując ekskursy w stronę eseistyki,

3 A. Fiut, Język wiary i niewiary [w:] tegoż, Pytanie o tożsamość, Kraków 1995, s. 141.

${ }^{4}$ Marek Zaleski zauważył, iż „uznanie dokonało się poprzez skandalizowanie [Herberta W.L.] wypowiedzi, zwłaszcza tych wygłaszanych u schyłku życia. (...) Trafił [on - W.L.] w okopy wojny kulturowej, toczącej się w Polsce od lat dwudziestu. (...) Trzeba tu dodać, że obecność Herberta zmienia się niekiedy w komedię omyłek, także prokurowanych przez przyjaciół tej poezji. (...) Nieobca [poecie - W.L.] była wiedza, że wartości nam drogie są nierzadko trudno uzgadnialne wzajemnie lub zgoła sprzeczne i wchodzą ze sobą w kolizje: (tenże, Herberttrickster [w:] Nagta wyspa. Studia i szkice o pisarstwie Zbigniewa Herberta, red. P. Próchniak, Lublin 2015, s. 17-19).

5 Por. A. Zagajewski, Wiersze Herberta, które lubię najbardziej [w:] tegoż, Poezja dla początkujacych, Warszawa 2017, s. 140-143. 
pozostawiając na uboczu lekturę dramatów i listów. Oczywiście zdaję sobie sprawę z tego, że pisma prozatorskie - eseistyczne, literackie, krytyczne ${ }^{6}$, a także varia oraz przekłady, publikowane w prasie wywiady z Herbertem znacznie poszerzyły obszar herbertologicznych badań i dociekań. Największe zasługi w przywracaniu utworów Herberta społecznej pamięci mają dwie oficyny Zeszyty Literackie oraz Wydawnictwo a5.

Początki utonęły w niepamięci, znane były fragmentarycznie bądź niedokładnie. Teraz, w innym już czasie, różnym od historycznych realiów, w których wiersze powstawały, dowiadujemy się o punktach wyjścia pisarstwa Herberta. Debiut książkowy Struna światta (1956) przysłonił wcześniejsze jego poszukiwania, a ponad trzydziestoletni pisarz objawił się czytelnikom jako artysta dojrzały, o ukształtowanej osobowości artystycznej ${ }^{7}$, choć przecież wpisywano te utwory w porządek ówczesnej młodej poezji traktowanej en bloc . Struna światta została zauważona przez krytykę tak jak inne „obiecujące” debiuty, a jedynie Kazimierz Wyka poświęcił zbiorowi recenzję-rozprawkę? ${ }^{\text {. Na- }}$ tomiast po roku kolejny tom Hermes, pies $i$ gwiazda spotkał się z większym zainteresowaniem. Wymieńmy tu między innymi szkice Anny Kamieńskiej, Jerzego Kwiatkowskiego, Ryszarda Matuszewskiego ${ }^{10}$.

Tomy Studium przedmiotu (1961) i Napis (1969) miały odbiór szeroki. Poeta umocnił się na pozycji klasycysty, choć w jego wierszach dostrzeżono też inne wymiary sensów. Większy odzew wywołał tom Barbarzyńca w ogrodzie (1962). Można powiedzieć półżartobliwie, iż wówczas wybuchła powszechna dyskusja o tym, kto jest „barbarzyńcą”. Przebywający za żelazną kurtyną - po katastrofie wojennej i politycznej - zapragnęli powrotu do źródeł wielkiej sztuki. Według Romana Zimanda: „(...) barbarzyńcą w ogrodzie jest człowiek w tworzonym i niszczonym przez siebie ogrodzie kultury, w którym chwilowej (?) - wieczystej (?) możności opanowania chaosu najlepiej dowodzą

${ }^{6}$ Z. Herbert, Labirynt nad morzem, Warszawa 2000; tenże, Węzet gordyjski oraz inne pisma rozproszone 1948-1998, oprac. P. Kądziela, Warszawa 2001; tenże, „Mistrz z Delft” i inne utwory odnalezione, oprac. B. Toruńczyk, współpraca H. Citko, Warszawa 2008; tenże, Gtosy Herberta, oprac. B. Toruńczyk, Warszawa 2008; Herbert nieznany. Rozmowy, oprac. H. Citko, Warszawa 2008.

7 Zob. E. Balcerzan, Arkadyjczyk w oblężonym mieście (O poezji Zbigniewa Herberta), „Twórczość" 1986, nr 10, s. 39-40. Zob. też J. Błoński, Zbigniew Herbert [w:] Poznawanie Herberta, wybór i wstęp A. Franaszek, Kraków 1998, s. 22, pierwodruk: „Życie Literackie” 1955, nr 51, s. 5.

${ }^{8}$ Por. J. Łukasiewicz, Zbigniew Herbert i rok 1956 [w:] Herbert (nie)oswojony, red. W. Browarny, J. Orska, A. Poprawa, Wrocław 2008, s. 37-38.

9 K. Wyka, Sktadniki świetlnej struny, „Życie Literackie” 1956, nr 42, przedruk [w:] tegoż, Rzecz wyobraźni, Warszawa 1959, s. 238-249 (wyd. 1).

10 A. Kamieńska, Niewierny Tomasz i świat, „Twórczość” 1957, nr 10-11, s. 153-156; J. Kwiatkowski, Klerk mężny, „Życie Literackie” 1957, nr 40, s. 4, 9, przedruk: Imiona prostoty [w:] tenże, Klucze do wyobraźni, Warszawa 1964, s. 265-279, w tej wersji szkic dotyczy także Studium przedmiotu; R. Matuszewski, Wiersze piękne i rozumne [w:] tegoż, Doświadczenia i mity, Warszawa 1964, s. 348-352, pierwodruk: „Nowa Kultura” 1957 nr 48, s. 6. 
arcydzieła" ${ }^{11}$. Raj estetów dla Herberta nie był jednak dostępny, gdyż poeta nie mógł przekreślić pamięci o złych dziejach, wyrzec się programu etycznego, ale też pojawiał się rozziew między tym, co przygodne i zmienne w pojedynczej egzystencji, a niedająca się dosięgnąć doskonałością arcydzieł.

Choć twórczość Zbigniewa Herberta była zauważana i doceniana, to jednak szczyt powodzenia osiągnął pięćdziesięcioletni wówczas poeta, kiedy na rynku czytelniczym pojawił się zbiór zatytułowany Pan Cogito (1974). Zdobyte wysokie notowania artystyczne i zarazem etyczne potwierdził Raport z oblężonego Miasta (1983), najbardziej znaczący tom z czasów stanu wojennego w Polsce. Przestanie Pana Cogito traktowano jak katechizm Polaków aspirujących do wolności, chociaż moralnych wskazań poeta wcale nie przypisywał do jakiegokolwiek momentu historycznego ${ }^{12}$, lecz dodać należy, że lektura aktualizująca narzucała się sama, wiersz stawał się bowiem upamiętnieniem $\mathrm{i}$,zadośćuczynieniem" dla walczących i cierpiących w czasie stanu wojennego ${ }^{13}$. Gdy w PRL-u szalała cenzura, utwory Zbigniewa Herberta wydawano w „Kulturze" paryskiej i przedrukowywano w drugim obiegu w Polsce. Kraj zniewolony przedstawiany był w postaci zbiorowo przeżywanego koszmaru (Pan Cogito powracał na „kamienne łono ojczyzny, [do - W.L.] „skarbca/ wszelkich nieszczęść" $\left.{ }^{14}\right)$, ale przecież wiersze Zbigniewa Herberta z przesłaniami głoszącymi duchową niezależność przynosiły wówczas tak bardzo upragnioną nadzieję.

Elegia na odejście (1990), podobnie jak tom Pan Cogito, stała się prawdziwym wydarzeniem literackim. Od tego punktu rozpoczyna się lektura Herberta jako poety metafizycznego ${ }^{15}$, który wierność pierwszym inicjacjom, przywoływanym w tonie elegijnym, przeciwstawiał refleksji na temat ostatecznych przeznaczeń. Kolejne zbiory: Rovigo (1992) oraz Epilog burzy (1992), również napotkały uważny rezonans krytyków, którzy zwracali uwagę na tematykę żalu, utraty, odchodzenia, studiowania śmierci.

W ostatnim tomie Zbigniewa Herberta - Epilogu burzy - dobitnie zaznaczają się wątki autobiograficzne zespolone z rozmyślaniami egzystencjalnymi. Język cierpienia brzmi tu naprawdę przejmująco. Jednakże lament nad

${ }_{11}$ R. Zimand, Ogród i barbarzyńca [w:] tegoż, Czas normalizacji. Szkice czwarte, Londyn 1989, s. 59.

${ }_{12}$ Zob. A. Nasiłowska, Zbigniew Herbert: Pan Cogito ma ktopoty [w:] Sporne postaci polskiej literatury wspótczesnej. Kontynuacje, red. A. Brodzka, L. Burska, Warszawa 1996, s. 24-25.

13 A. Michnik, Potęga smaku [w:] tegoż, $Z$ dziejów honoru w Polsce. Wypisy więzienne, Paryż 1985, s. 264.

14 Z. Herbert, Pan Cogito - powrót [w:] tegoż, Wiersze zebrane, oprac. R. Krynicki, Kraków 2008, s. 457-458.

15 Według Marty Wyki: „Podstawą tej metafizyki jest przeświadczenie (...) o przemijaniu indywidualnej postaci świata. Podróże Herberta stają się podróżami w stronę nicości, w stronę końca, ku śmierci" (taż, Herbert-poeta metafizyczny [w:] tejże, Niecierpliwość krytyki. Recenzje i szkice z lat 1961-2005, Kraków 2006, s. 146, pierwodruk: „Tygodnik Powszechny” 1990 nr 32). O dziejach czytania „Herberta metafizycznego” pisze między innymi M. Mikołajczak, Pomiędzy końcem i apokalipsą. O wyobraźni poetyckiej Zbigniewa Herberta, Wrocław 2007, s. 7-13. 
bolesnymi doznaniami ciała kontrastuje z uspokojonymi medytacjami eschatologicznymi. Wierność, pamięć i sumienie splatają się w tkaninę życia, nadając ludzkiemu doświadczeniu sens istotny. A zatem dołożyć wypadnie inne jeszcze nazwy: poeta cierpienia, odnowiciel stylu elegijnego, kreator słowa skierowanego w stronę doświadczeń granicznych. Wówczas, kiedy nasiliła się choroba poety, popularność jego dzieł istotnie wzrosła. Książki Herberta były: „łapczywie rozchwytywane, [a jednocześnie - W.L.] towarzyszyła im eksplozja rozpraw poświęconych Jego twórczości”"16.

Opisywane dzieło z czasem nabierało coraz większego znaczenia, mocno odciskając się w świadomości zbiorowej. Jednak warto też podkreślić, że dokumenty odbioru nawarstwiały się, komplikowały obraz twórczości Herberta, utwierdzając poczucie, iż recepcja jest wielonurtowa. Od samego początku o twórczości Zbigniewa Herberta pisali najwybitniejsi polscy krytycy oraz literaturoznawcy ${ }^{17}$ : Kazimierz Wyka (Sktadniki struny świetlnej, 1956), Jerzy Kwiatkowski (Imiona prostoty, 1963), Jan Błoński (Tradycja, ironia i głębsze znaczenie, 1970), Janusz Sławiński (Tren Fortynbrasa, 1963), Jan Józef Lipski (Między historiq i Arkadiq wyobraźni, 1962); Jacek Łukasiewicz (Studium przedmiotu, 1963), Jarosław Marek Rymkiewicz (Krzesto, 1970). Do tego wyliczenia dołączyć należy teksty późniejsze, bardzo ważne dla rozumienia Herberta, takie jak: Edwarda Balcerzana Arkadyjczyk w oblężonym mieście (1986), Stanisława Barańczaka O czym myśli Pan Cogito (1974), Tomasza Burka Herbert- linia wierności (1984), Krzysztofa Dybciaka W poszukiwaniu istoty i utraconych wartości (1978), Ryszarda Przybylskiego Między cierpieniem a forma (1978), Mariana Stali Rok 1983: gtos poety (1983). W kolejnym okresie recepcji, po wydaniu Elegii na odejście, umieścimy szkice Marty Wyki Herbert - poeta metafizyczny (1990), Jacka Brzozowskiego Antyk Herberta (1992), Przemysława Czaplińskiego Śmierć, czyli niedoskonatość (1995), Aleksandra Fiuta Jezzyk wiary i niewiary (1993), Piotra Śliwińskiego Poezja, czyli bunt (1995).

Odnotowanie wszystkich liczących się szkiców, które należą do tej sekwencji oraz w późniejszych latach wzbogacają refleksje o twórczości Herberta, nie wydaje się możliwe, gdyż jest ich wiele ${ }^{18}$. W tym miejscu nie ustrzeżemy się pewnej arbitralności. Dla potrzeb naszego szkicu konieczna jest informacja, że w długim okresie odbioru obejmującym sześć dekad (1956-2017) poezji, eseistyce oraz dramaturgii Zbigniewa Herberta prace krytyczne i literaturoznawcze poświęcili między innymi: Stanisław Balbus, Zbigniew Bieńkowski, Karl Dedecius, Janusz Drzewucki, Elżbieta Feliksiak, Krzysztof Karasek,

16 J. Hartwig, Pakiet listów [w:] Upór i trwanie. Wspomnienia o Zbigniewie Herbercie, red. K. Szczypka, Wrocław 2000, s. 27, przedruk [w:] Wierność. Wspomnienia o Zbigniewie Herbercie, wybór i oprac. A. Romaniuk, Warszawa 2014, s. 180.

17 Okres recepcji od pierwszych wypowiedzi krytycznych do „lektury etosowej” przedstawia A. Franaszek, Wstęp [w:] Poznawanie Herberta, dz. cyt., s. 8-14.

${ }_{18}$ Dokładny rejestr prac o Herbercie zob. P. Kądziela, Twórczość Zbigniewa Herberta. Monografia bibliograficzna, t. 1-2, Warszawa 2009. 
Andrzej Lam, Anna Legeżyńska, Zdzisław Łapiński, Włodzimierz Maciąg, Janusz Maciejewski, Ryszard Matuszewski, Arent van Nieukerken, Ryszard Nycz, Krystyna Pisarkowa, German Ritz, Artur Sandauer, Marian Stala, Piotr Śliwiński, Adam Zagajewski.

\section{Zasobna biblioteka}

Kolejny fragment w tych prolegomenach dotyczy książek poświęconych pisarstwu Zbigniewa Herberta. Debiutujący w 1950 roku poeta doczekał się całościowego spojrzenia na swą twórczość dopiero w roku 1982, w pracy Andrzeja Kaliszewskiego Gry Pana Cogito. Autor pierwszej monografii wybrał daleki od aktualności politycznej w PRL-u klucz lektury: śledził odniesienia do mitów, sytuował twórczość Herberta na tle tradycji literackiej i przymierzał jego wiersze do neoklasycyzmu ${ }^{19}$. Mocniejszą jednak pozycję zdobyła książka Stanisława Barańczaka Uciekinier z Utopii (pierwsze wydanie 1984). Autor ukazał antynomie twórczości Herberta, zasady, rodzaje i funkcje ironicznego mówienia, a także zakorzenienie tematów i przesłań w wartościach etycznych. Praca powstała w Stanach Zjednoczonych, poza PRL-owską cenzurą, dlatego w sposób swobodny mogła zostać ukazana walka poety z opresją totalitarną. Niejako przy sposobności Stanisław Barańczak prostuje „nieporozumienia” narosłe wokół „zachodniofilstwa”, ukazuje też względność aneksji pisarstwa Herberta przez program klasycyzmu, dowodząc, że żadnej z tych kategorii nie można absolutyzować. Tak Zbigniew Herbert $\mathrm{z}$ autoironią charakteryzował odczytanie Barańczaka, układając jednocześnie celną, lapidarną recenzję Uciekiniera z Utopii: „żaba jest wdzięczna, żeś ją wyprowadził z pustyni klasycystów, przywrócił wyobraźnię zmysłową, zauważył jej (żaby) niechęć do moralizatorstwa, nienawiść do utopii, a także usytuował trafnie między biegunami dziedzictwa i wydziedziczenia" 20 .

W latach dziewięćdziesiątych XX wieku wzmaga się zainteresowanie twórczością Herberta. Wtedy powstaje wiele monografii, w których zwykle punkt widzenia usytuowany jest blisko tekstów poetyckich oraz eseistycznych.

19 Ta problematyka znajduje kontynuację w rozprawie A. Kaliszewskiego, Klasycyzujący antyklasyk (Zbigniew Herbert) [w:] tegoż, Nostalgia stylu. Neoklasycyzm liryki polskiej XX wieku w krytyce, badaniach i poetykach immanentnych (w kontekście tradycji poetologicznej klasycyzmu), Kraków 2007. Piotr Śliwiński zwraca uwagę na połączenie dwóch biegunów poetyki klasycystycznego oraz awangardowego w wierszach Herberta, pisząc: „powinowactwo klasycyzmu i awangardy polegałoby (...) na występowaniu trojakich wspólnych właściwości: pierwsza to opieranie się na założeniach, programie, regułach; druga - traktowanie twórczości jako akcji; trzecia - uprzywilejowanie rzeczywistości i formy w stosunku do osobowości autora" (tenże, Porywczość formy [w:] Nagta wyspa..., dz. cyt., s. 197-198).

${ }^{20}$ List z 6 XII 1983 [w:] Z. Herbert, S. Barańczak, Korespondencja, red., oprac. B. Toruńczyk, Warszawa 2005, s. 14. 
Wskażmy kolejne istotne próby „przekrojów i zbliżeń”: Danuty Opackiej-Walasek „...pozostać wiernym niepewnej jasności”. Wybrane problemy poezji Zbigniewa Herberta (1996) oraz Marka Adamca „...Pomnik troche niezupetny...". Rzecz o apokryfach i poezji Zbigniewa Herberta (1996). W zaproponowanej lekturze Opacka-Walasek wprowadza kategorię „budowania ładu aksjonormatywnego", zajmuje się między innymi poetyckimi formami zapisów pamięci, wartościami kształtującymi postawę moralistyczną, wreszcie - sztuką podróżowania. Natomiast Adamiec, pozostawiając na boku kwestie społecznego oddziaływania poety, eksponuje intertekstualność, która odnosi się do świętych ksiąg, ważnych w dziejach kultury opowieści, źródeł historycznych, mitologii, sztuki malarskiej, architektonicznej, muzycznej.

Z kolei Piotr Siemiaszko, autor pionierskiej monografii eseistyki Herberta Zmienność i trwanie (1996) - umieszczoną w tytule antynomię odnosi do kilku porządków: ontologicznego, epistemologicznego, etycznego. Badacz udowadnia, iż destrukcyjnej zmienności natury i nieustannemu zagrożeniu człowiek Herberta przeciwstawia enklawy ładu, jakie tworzą dzieła malarskie. Rekonstrukcje inspiracji filozoficznych łączą się tutaj z rozważaniami poświęconymi wtajemniczeniom pisarza w historię sztuki. Natomiast w książce Andrzeja Franaszka Ciemne źródto (o twórczości Zbigniewa Herberta) (1998) na plan pierwszy wysuwa się kwestia cierpienia, którego nie można oderwać od ludzkiego losu, a więc trzeba je przyjąć i zrozumieć. W tym ujęciu inne rodzaje bólu i rozpaczy mają swe źródła $\mathrm{w}$ przeżywaniu osobnego bycia w świecie, a także w niezbywalnym pragnieniu prawdy. Osobny przedmiot namysłu tworzą w Ciemnym źródle rozważania o metafizycznym skandalu śmierci, o „konsekwentnym postrzeganiu człowieka w perspektywie jego śmiertelności”21.

Ciekawy pomysł lektury konsekwentnie zrealizował Julian Kornhauser w książce Uśmiech Sfinksa (2001). Otóż poeta, krytyk i badacz, eksponując związki utworów poetyckich z biografią pisarza, w odczytywaniu następujących po sobie wierszy w kolejnych tomach ukazał przemianę głównych Herbertowskich idei - od przeżywania wojennej traumy i poszukiwania stałych punktów oparcia w kulturze w Strunie światta po ostateczny rozrachunek z życiem i pisaniem w Epilogu burzy.

${ }^{21}$ A. Franaszek, Ciemne źródto (o twórczości Zbigniewa Herberta), Londyn 1998, s. 165. Książka Franaszka lokuje się u początków badań nad tematem cierpienia i śmierci u Herberta. Pole badawcze określił Ryszard Przybylski w eseju Między cierpieniem a forma [w:] Poznawanie Herberta, dz. cyt. Zob. między innymi P. Czapliński, Śmierć, czyli o niedoskonatości [w:] Poznawanie Herberta, dz. cyt., s. 280-303; P. Panas, Herbertowe „ars moriendi” [w:] Wyraz wytuskany z piersi. Szkice o twórczości Zbigniewa Herberta, red. B. Gautier, D. Knysz-Tomaszewska, J.M. Ruszar, M. Zieliński, Lublin 2006, s. 218-230; D. Zawistowska-Toczek, Droga ku śmierci. Ostatni towarzysze Starca, ostatnie rozmowy i samotność cierpienia (oraz rozdziały następne) [w:] tejże, Stary poeta. „Ars moriendi” w późnej twórczości Zbigniewa Herberta, Lublin 2008, s. 333 i n.; K. Pietrych, Spotkanie drugie: Zbigniew Herbert [w:] tejże, Co poezji po bólu. Empatyczne przestrzenie lektury, Łódź 2009, s. 77-104. 
Odmianę szlachetnej popularyzacji reprezentuje - oparta na wieloletnim obcowaniu z dziełem - znakomita praca Jacka Łukasiewicza Herbert $(2001)^{22}$. W żywym wywodzie, bez uproszczeń i pominięć, zostają przybliżone dzieje prywatne poety oraz najważniejsza problematyka tego pisarstwa, przejrzyście podana w rozdziałach o mieście (utraconym Lwowie), powojennych dziejach - człowieka i artysty, współczuciu, podróżach, mitach, genealogii kulturowej i postaci Pana Cogito, historii, o Bogu i transcendencji, o chorobie i śmierci. Do tej samej kategorii zaliczyć należy poprzedzone instruktywnym wstępem interpretacje $\mathrm{Da}$ nuty Opackiej-Walasek Czytając Herberta (2001) adresowane do studentów obcokrajowców, ale na pewno rozleglejszy jest w tym przypadku horyzont odbioru.

W precyzyjnych wywodach w książce zatytułowanej „W cieniu heksametru”. Interpretacje wierszy Zbigniewa Herberta (2004) Małgorzata Mikołajczak rozpoznaje znaczenia wariacji i nawiązań do antycznej formy wiersza („,6-akcentowca tonicznego"), ukazując szerokie pole odniesień do tradycji literackiej i dialogu z polskimi poetami. Forma wierszowa ma tutaj ścisły związek z semantyką wypowiedzi poetyckiej. Tak oto ukazane zostają preferencje estetyczne Herberta oraz umiłowanie mowy wzniosłej, ale przede wszystkim klasycyzm tego poety. Piotr Michałowski oddał istotę tej książki w celnym określeniu „sześć stóp kultury”23.

Małgorzata Mikołajczak, która należy do najwybitniejszych znawców poezji Herberta, w kolejnych książkach systematycznie rozszerza obszar własnych badań. Monografię zatytułowaną Pomiędzy końcem a apokalipsą. O wyobraźni poetyckiej Zbigniewa Herberta (2007) uznać należy za rodzaj summy opisów świata poetyckiego autora Epilogu burzy. Badaczka rozlicza się ze stanem badań i porządkuje koncepty lektury, w centrum uwagi umieszczając „metafizyczną wyobraźnię poety rozumianą jako sferę obrazowania syntetyzującą przestrzeń, czas oraz pozostałe elementy świata przedstawionego w relacji do metafizycznych aspektów egzystencji” ${ }^{24}$. Do tych składników wyobraźni należą między innymi relikty katastrofy oraz obrazy końca (tutaj istotne są nawiązania do poetów drugiej awangardy i poetów pokolenia wojennego), tradycja mityczna - od Biblii do mitu orfickiego, motywy sztuki ocalającej, ekwiwalenty obrazowe marnego czasu historii, ujęcia poetyckie przestrzeni nieruchomej, pokusy nihilizmu i wyobrażenia związane $\mathrm{z}$ wiarą możliwą i niemożliwą, jak również zorientowanie wrażliwości skierowane ku „ziemi jałowej” T.S. Eliota.

W pracy Światy z marzenia badaczka umieszcza twórczość poety w trzech układach odniesienia: tradycji szekspirowskiej, norwidowskiej i romantycznej - polskiej. Posługując się metaforą rozbitej liry Orfeusza, zwracając uwagę na próby odbudowania w słowie ładu świata, Małgorzata Mikołajczak pisze o intertekstualnym dialogu z kluczową (wieszczą, wolnościową)

${ }^{22}$ Wskazać też należy zbiór interpretacji: J. Łukasiewicz, Poezja Zbigniewa Herberta, Warszawa 1995.

${ }^{23}$ Szkic Michałowskiego pod tym tytułem ukazał się w „Rzeczpospolitej” (2004, nr 241).

${ }^{24}$ M. Mikołajczak, Pomiędzy końcem a apokalipsa..., dz. cyt., s. 37. 
tradycją literatury polskiej. Jednocześnie podkreśla, że ironiczna dykcja Herberta obejmuje „negatywną recepcję postaw i przekonań stereotypowo łączonych z romantyzmem" ${ }^{25}$. Szczególnie inspirujące są w tej książce rozważania o znaczeniach muzyczności w utworach Herberta, etycznych odniesieniach sztuki, przekształceniach motywów romantycznych, o „patronacie” Hamleta i Szekspira. Dużą wartość poznawczą mają też odczytania Utworów rozproszonych - w odniesieniu do kulturowego spadku przeszłości.

Oczywiście zatrzymuję się przy kilku przypadkach znamiennych w historii czytania Herberta ${ }^{26}$. Kolejna faza komentowania, którą już zacząłem charakteryzować, wiąże się z systematycznymi badaniami prowadzonymi w wyższych uczelniach, wspieranymi przez instytucje kulturalne. Pamiętać należy o licznych sympozjach naukowych, warsztatach, spotkaniach integrujących badaczy z różnych środowisk akademickich. W powstałych pracach mocniej niż dotąd zaznacza się podejście specjalistyczne - literaturoznawcze. $Z$ tego rodzaju inicjatywami wiążą się tomy zbiorowe ${ }^{27}$.

W tym miejscu trzeba podkreślić znacząca rolę wychodzącej od roku 2004 serii wydawniczej „Biblioteka Pana Cogito”. Indywidualne tomy i prace zbiorowe, które należą do tej kolekcji, poszerzają pole refleksji o nowe ujęcia filozoficzne i estetyczne, nowe konteksty, w którym ta twórczość jest rozpatrywana. Jednocześnie należy dostrzec, że w opisywanych badaniach dokonuje się pokoleniowa zmiana warty, gdyż głosy młodych znawców Herberta zyskują na znaczeniu, o czym świadczą prace zbiorowe, między innymi Czutość dla Minotaura (2005), Dialog i spór (2006), Pojęcia kietkujace z rzeczy (2010), w jakiejś mierze antologia interpretacji Gaszcz srebrnych liści (2015) oraz zbiory Literatura i fenomenologia. Zbigniew Herbert i Tadeusz Różewicz w kręu myśli Ingardenowskiej (2016), a także książki autorskie Anny Mazurkiewicz-Szczyszek $W$ asyście jakich dzwonów. Obrazy miasta w twórczości Zbigniewa Herberta (2008), Dagmary Zawistowskiej-Toczek Stary poeta. „Ars moriendi" w późnej twórczości Zbigniewa Herberta (2008), Mateusza Antoniuka Otwieranie gtosu. Wczesna twórczość Zbigniewa Herberta (1948-1957) (2009), Między nami a świattem. Bóg i świat w twórczości Zbigniewa Herberta (2012)

${ }_{25}$ M. Mikołajczak, Światy z marzenia. Echa romantyczne w poezji Zbigniewa Herberta, Zielona Góra- Kraków 2013, s. 72.

${ }^{26}$ Poprzestaję tylko na wzmiance o rozbudowanej pracy Bogdana Urbankowskiego, Poeta, czyli cztowiek zwielokrotniony. Szkice o Zbigniewie Herbercie, Radom 2004. Jest to zamierzenie niezwykle ambitne poznawczo, autor pragnie skonstruować szczegółową monografię, jednakże takie praktyki, jak zawłaszczanie przez siebie pierwszeństwa spostrzeżeń, deprecjonowanie badań, a także zacietrzewienie publicystyczne, obniżają wartość tej książki.

${ }^{27}$ Czytanie Herberta, red. P. Czapliński, P. Śliwiński, Poznań 1995; Twórczość Zbigniewa Herberta, red. M. Woźniak-Łabieniec, J. Wiśniewski, Kraków 2001; Herbert i znaki czasu. Colloquia Herbertiana, red. E. Feliksiak, M. Leś, E. Sidoruk, t. 1: Białystok 2001, t. 2: Białystok 2002; Herbert. Poetyka, wartości i konteksty, red. E. Czaplejewicz, W. Sadowski, Warszawa 2002; Niepewna jasność tekstu. Szkice o twórczości Zbigniewa Herberta 1998-2008, red. J.M. Ruszar, Kraków 2009. 
Magdaleny Śniedziewskiej Wierność rzeczywistości. Zbigniew Herbert o postawie wobec świata i problemach jego reprezentacji (2013). Ta ostatnia książka ma postać albumu z reprodukcjami dzieł malarskich przywoływanych w pisarstwie autora Martwej natury z wędzidtem.

W rozwijaniu „ruchu Herbertowskiego” znaczne zasługi położył badacz tej twórczości, inicjator konferencji naukowych, kierownik Warsztatów Herbertowskich dla młodych literaturoznawców, projektodawca i redaktor „Biblioteki Pana Cogito”, twórca i redaktor internetowego portalu Herbert. guru - Józef Maria Ruszar, który jest autorem książek Stróż brata swego. $Z a-$ sada odpowiedzialności w liryce Zbigniewa Herberta (2004), Stońce republiki. Cywilizacja rzymska w twórczości Zbigniewa Herberta (2014), Wytarty profil rzymskich monet. Ekonomia jako temat literacki w twórczości Zbigniewa Herberta (2016). Już same tytuły wskazują na przechodzenie od problematyki etyczno-filozoficznej do kwestii odniesień cywilizacyjnych, do „kontekstu historyczno-kulturowego, a także dorobku tak różnych dziedzin wiedzy, jak historiozofia czy koncepcje rozwoju gospodarczego" 28 oraz, niejako równolegle, opisywany dialog obejmuje tradycję literacką - głównie romantyczną. Trzecia z książek Ruszara, w której punktem wyjścia jest dziedzictwo cywilizacyjne Grecji i Rzymu w starożytności, poświęcona została pozornie peryferyjnemu tematowi zainteresowań ekonomicznych Zbigniewa Herberta, popartych wykształceniem w tym kierunku, lecz owocujących w poezji oraz sztuce eseju, w obrazowaniu, metaforyce i poznawczych walorach. Herbert jawi się tutaj jako szczególnego rodzaju znawca, pasjonat i krytyk zagadnień gospodarczych oraz finansowych w wielowiekowej historii Europy.

W latach ostatnich przeważa typ monografii ukazującej historię wybranego tematu w twórczości Herberta. Rozważania i rozbiory koncentrują się wokół takich haseł, jak sacrum, malarstwo, miasto, starość, poglądy estetyczne, filozofia twórcza i szeroko rozumiany dialog z myślą filozoficzną czy humor jako narzędzie poznania. Pojawiają się pytania, jak zastana topika literacka zmienia się w Herbertowym pryzmacie, w jaki sposób czytanie kulturowe ujawnia specyfikę pisarstwa Herberta. I wreszcie - czy pierwsze pisarskie próby oświetlają dojrzałe dokonania tego poety. Nie sposób w pojedynczym artykule przybliżyć całe bogactwo problematyki twórczości Herberta opisane we - wciąż przyrastającej - bibliotece prac.

\section{Cztery przekroje}

Wybieram cztery przypadki rozmaitych pól problemowych oraz metod postępowania badawczego. Ten znamienny rozrzut tworzą „krytyka genetyczna”, czyli poparte studiowaniem rękopisów poety rozważania o kształtowaniu się

${ }^{28}$ J.M. Ruszar, Stońce republiki. Cywilizacja rzymska w twórczości Zbigniewa Herberta, Kraków 2014, s. 19. 
warsztatu pisarskiego Herberta (Mateusz Antoniuk, Otwieranie gtosu. Studium o wczesnej twórczości Zbigniewa Herberta (do 1957 roku), 2009), refleksje komparatystyczne na temat zachodnich odniesień dzieła polskiego poety, czyli Jolanty Dudek, Granice wyobraźni, granice stowa. Studia z literatury porównawczej XX wieku (omawiam tu obszerny szkic, a właściwie małą monografię Zbigniew Herbert wobec T.S. Eliota, 2008), kierunek dociekań estetyczno-filozoficznych i dyskusję o sytuacji sztuki, kiedy rozpada się wiara w zbawienie przez piękno (Karol Hryniewicz, Cogito i dubito. Dyskurs estetyczny w poezji Zbigniewa Herberta $i$ Tadeusza Różewicza, 2014) oraz studium o specyficznym wyzyskaniu w tej twórczości komizmu, humoru, a także funkcji postawy żartobliwej stowarzyszonej z ironią (Agnieszka Kramkowska-Dąbrowska, Gabinet luster. Śmiech w twórczości Zbigniewa Herberta, 2015).

W książce Mateusza Antoniuka powstaje wielowymiarowy „portret artysty z czasów młodości”, który rozwija świadomość twórczą, szuka uzasadnień wybranych wartości, odrzuca kuszenia propagandy lat pięćdziesiątych, wreszcie - układa strategię debiutu i marzy o tym, by wybić się na pisarską niepodległość. Przegląd archiwum dokonany przez Antoniuka przynosi rezultaty, które znawców tego pisarstwa będą obowiązywać przez lata. Ukazane zostają formy oraz przewodnie idee poszukiwań młodego Herberta. Jeśli nie znamy ineditów, nie dotrzemy do tajemnic warsztatu pisarskiego, nie zrozumiemy w pełni dojrzałej twórczości. Niezwykle interesująca jest literaturoznawcza opowieść o tym, jak i kiedy debiutujący anonim przekształcił się w czytanego (i podziwianego) poetę.

W Otwieraniu gtosu problematyka periodyzacji twórczości Herberta wiąże się z kwestią podejmowanych kolejno prób wypowiedzi w różnych rodzajach literackich i gatunkach. Badacz prowadzi wywód wielotorowo, gdyż w książce znajdziemy zagadnienia porównawcze, refleksje o języku poetyckim, studia nad tekstami oraz sprawozdania z poszukiwań w archiwum pisarza. Zwróćmy uwagę na dwie narracje związane z początkami twórczości Herberta: o autorskim „micie inicjacyjnym” przekreślającym zależności od poetów pokolenia wojennego oraz o stylizowanym na dziennik duchowy otwarciu tej twórczości (dotąd nie był znany Journal metaphisique Herberta). Kolejna próba głosu to zachowany w notatniku Herbertowy przekład wiersza Reinera Marii Rilkego Dzień jesienny, ze znawstwem w książce zanalizowany.

Oto istotne założenie, którym kieruje się badacz: „Twórczość Zbigniewa Herberta można i warto opisywać jako pole eksperymentu, w obrębie którego poszczególne formy gatunkowe wyłaniają się lub znikają, uzupełniają się lub konkurują, są obecne trwale albo efemerycznie" ${ }^{29}$. W tej książce Herbert jawi się jako pisarz rozmyślający o miejscu człowieka w świecie, o jego tożsamości oraz kształtowaniu indywidualnego ,ja”. W każdym z gatunków ta problematyka

${ }^{29}$ M. Antoniuk, Otwieranie gtosu. Studium o wczesnej twórczości Zbigniewa Herberta (do 1957 roku), Kraków 2009, s. 97. 
przedstawia się inaczej: we wczesnych prozach powojennych rozpad tożsamości bohaterów sięga tak daleko, że podmiot przemienia się w przedmiot. Natomiast w dramacie Jaskinia filozofów enigmat bycia kimś odrębnym mocno się ujawnia, ponieważ bohater osaczony zostaje przez wielość własnych wizerunków. Mateusz Antoniuk pisze o osłabianiu podmiotu autorskiego i o tym, że rozrost liryki roli w konsekwencji musiał doprowadzić do wykreowania postaci Pana Cogito.

Istotny jest tutaj fragment poświęcony małym utworom prozatorskim Zbigniewa Herberta, które zostają nazwane „palimpsestowymi poematami prozą" ${ }^{30}$. Autor rozprawy zastanawia się nad wyzwaniem, jakim dla Herberta był pojedynek z wielką formą epicką. Chodzi tutaj o kilka zachowanych stronic „powieści o czasie”. W kolejnych rozdziałach Antoniuk powraca do notatników z archiwum Herberta. Przybliża wędrówki słów między tekstami, śledzi rozrost wypowiedzi ze szkicowych zawiązków-zapisów, omawia wersje alternatywne. Wiedza i wyobraźnia badacza podążają za decyzjami artystycznymi poety i w jakimś sensie je odtwarzają.

Natomiast w książce Granice wyobraźni, granice stowa Jolanta Dudek na przykładzie Herberta i Różewicza ukazuje skomplikowaną problematykę promieniowania na poezję polską ważnych kierunków nowoczesności przetransponowanego symbolizmu, imagizmu, wortycyzmu, odnowionego klasycyzmu. W tej pracy rozwija się dwutorowa narracja o literaturze polskiej i anglosaskiej, o wartościach estetycznych, przesłaniach filozoficznych, artyzmie i związkach z czasem historycznym. I, co wydaje się niebagatelne, w konfrontacji z arcydziełami literatury światowej odsłania się wysoka ranga poezji Zbigniewa Herberta i Tadeusza Różewicza. Jolanta Dudek odnotowuje różnice $\mathrm{w}$ rozumieniu pojęć, przesunięcia w czasie innowacyjnych rozwiązań, odmienność tradycji myślenia i kulturowych wyobrażeń na Zachodzie i w Polsce. Postawienie sprawy jest ostrożne: wyeksponuje się mianowicie reguły analogii, translacji, transpozycji, współbrzmienia.

Centralne miejsce w tym wykładzie zajmują kwestie pamięci oraz wyobraźni. Oba te wymiary znaczeń odczytywanych w utworach Eliota i Herberta realizują się w odniesieniach do tradycji Myśli Blaise Pascala ${ }^{31}$, w koncepcji wyobraźni pojmowanej jako „zjednoczona wrażliwość" 32 integrująca podmiot wypowiedzi, myśleniu historycznym, dyskursach empatii i wierności, w modernistycznym obiektywizowaniu uczuć, wreszcie - w diagnozach antropologicznych bierności oraz pałubiczności. Badaczka ze swobodą i świetną znajomością rzeczy sięga po konteksty nowoczesnej literatury powszechnej oraz

30 Tamże, s. 132.

31 Jolanta Dudek pisze, iż: „Wyobraźnia Pana Cogito nastawiona jest (...) na rejestrowanie i ustanawianie przeciwnego naturze porządku "współczucia», które zalecał Pascal wobec ludzi nadaremnie poszukujących ukrytego Boga" (taż, Granice wyobraźni, granice stowa. Studia z literatury porównawczej XX wieku, Kraków 2008, s. 38).

32 Tamże, s. $41 \mathrm{i} \mathrm{n.}$ 
współczesnej obu pisarzom filozofii. Wskazane paralele oraz zbliżenia ukazane tu zostały przez porównania konkretnych utworów Eliota i Herberta (z lat 1983-1998). Oto przykłady takich par tekstowych: Cztery kwartety oraz Pan Cogito i wyobraźnia, La Figlia che Piange i Czutość, a także Kwiaty, Sroda Popielcowa i Do Ryszarda Krynickiego - list.

Terytorium obserwacji zmienia się w książce Karola Hryniewicza Cogito i dubito. Dyskurs estetyczny w poezji Zbigniewa Herberta i Tadeusza Różewicza (2014). Autor uwypukla rolę teorii w eksplikacji zagadnień estetycznych w poezji Różewicza i Herberta oraz związanych z tym kręgiem refleksji dyskursów poetyckich odnoszonych do prób zrozumienia późnej nowoczesności. Opisuje sposoby myślenia poetów o sztuce nowoczesnej, a także podejmuje namysł nad idiomami, obrazami, pojęciami oraz odmianami dialogu z estetyką współczesną w utworach tych dwóch wybitnych polskich poetów XX wieku. W swej pracy Karol Hryniewicz zajmuje się odbiciami powszechnych wyobrażeń dotyczących sztuki - w unikatowym widzeniu poetyckim.

Ważne miejsce w tworzonym leksykonie pojęciowym zajmują ,imaginaria" Charlesa Taylora - przekroczone, zniesione, zakwestionowane przez wojenne przeżycie pokoleniowe (kanadyjski filozof w Źródtach podmiotowości pisze o Różewiczu i Herbercie). W rozważaniach Hryniewicza istotną rolę odgrywają „sytuacja estetyczna” oraz próby estetycznego wartościowania. Jak pisze autor: „Herbertowskie myślenie o sztuce i estetyce zdeterminowane jest (...) przyjętą przez niego postawą aksjologiczną. Skłonność poety do obiektywizowania (...) implikuje (...) postawę esencjalistyczną względem sztuki, a więc przeświadczenie o jej uniwersalnej i ponadczasowej istocie"33. Wyróżnić tutaj należy triadę w dyskursie estetycznym: podmiot - praxis - sztuka. Wśród wielu pojawiających się wątków wyróżniają się porównania wierszy Herberta z Listami o estetycznym wychowaniu cztowieka Fryderyka Schillera (rzecz obejmuje między innymi terapeutyczną i wychowawczą rolę estetyki, relacje interpersonalne oparte na wartościach etycznych, historiozofię i politykę), zestawienia Herberta rozważań o smaku z ideami Anthony’ego Ashleya Coopera Shaftesbury'ego, oryginalne spostrzeżenia dotyczące „figury przepaści” bądź topiki otchłani. Istotne dopowiedzenia znajdziemy w rozdziale „Najpiękniejszy jest przedmiot, którego nie ma" - o estetycznej funkcjonalizacji kategorii braku, w którym autor zestawia myślenie o sztuce Herberta z Elzenbergowską ontologią wartości, a szczególnie - ze statusem piękna w tej doktrynie estetycznej.

Rekonstruowany obraz pisarstwa byłby niepełny, gdybyśmy pominęli kategorię humoru poetyckiego. W życiu i pisaniu Herberta Julia Hartwig wyróżnia wiele odmian, takich jak ,żart swobodny, żart ironiczny, żart sarkastyczny" ${ }^{34}$. Wskazaną lukę w badaniach literaturoznawczych wypełnia książka Agnieszki

${ }^{33}$ K. Hryniewicz, Cogito i dubito. Dyskurs estetyczny w poezji Zbigniewa Herberta $i$ Tadeusza Różewicza, Kraków 2014, s. 85-86.

${ }^{34}$ J. Hartwig, dz. cyt., s. 27. 
Kramkowskiej-Dąbrowskiej Gabinet luster. Śmiech w twórczości Zbigniewa Herberta. Jeśli w tekstach naukowych i krytycznych pojawiały się uwagi o humorze poetyckim, postawie ludycznej, grotesce, to miały one charakter incydentalny. Teraz wskazana problematyka wydobyta została na plan pierwszy - zresztą ze świetnymi rezultatami poznawczymi. Agnieszka Kramkowska-Dąbrowska opisała rozległe i zmienne obszary znaczeniowe śmiechu w praktyce twórczej Herberta. W tym ujęciu na uwagę zasługują subtelne sploty humoru i myślenia filozoficznego, kontrasty między stylem a przedmiotem wypowiedzi, napięcia, jakie powstają pomiędzy naiwną, „dziecinną" postawą wobec świata a zjadliwą demaskującą ironią. Takie właściwości pisarstwa Herberta, między innymi wyjątkowe w polskiej poezji gry personą liryczną oraz pełen inwencji humor słowny, zostały w książce Gabinet luster celnie i precyzyjnie przybliżone.

Temat śmiechu w pisarstwie Herberta ma naturę proteuszową, gdyż w refleksji o przemianach humorysty, ironisty i satyryka Kramkowska-Dąbrowska uwzględnia chronologię twórczości - okres „otwierania”, czy też kształtowania głosu pisarskiego, czasy debiutu i rosnącej popularności poety, fazę twórczości dojrzałej, medytacje elegijne i egzystencjalne - pożegnania oswajane przez humor. Różne odcienie śmiechu wiążą się u Herberta z polifonią literacką, intertekstualizmem, relacjami $\mathrm{z}$ „mową cudzą”. Rodzaj śmiechu zmienia się w zależności od konwencji gatunkowej, a także - w związku z ocenami zjawisk rozciaggającymi się od bezinteresownego humoru, poprzez wieloznaczny uśmiech, śmiech wojujący - satyryczny, dotykający społecznej aktualności, do bezlitosnej ironii i deformującej obraz świata groteski. Śmiech poważny, jakkolwiek może to zabrzmieć jak oksymoron, wzmacnia namysł filozoficzny, tworzy dystans wobec cierpienia, choć go nie likwiduje. Jak udowadnia badaczka, jakości żartobliwe u Herberta spotykają się z językiem dziecka i dziecięcym odbiorem świata. W tej pracy osobny nurt rozważań poświęcony został językowi poetyckiemu, humorowi słownemu, grotesce i jej powiązaniom z dyskursem o cierpieniu i dyskursem katastroficznym. Dużą zasługą autorki jest przywrócenie świadomości odbiorców wizerunku Herberta satyryka.

\section{Blisko tekstów}

Szczególnie po śmierci poety w roku 1998 nastąpił znaczący przyrost tekstów literaturoznawczych. Zaobserwować należy przesunięcie odbioru pisarstwa autora Pana Cogito z domeny krytyki literackiej w strefę nauki o literaturze. Intuicje i hipotezy, wynikające ze „słuchu literackiego”, a także rozpoznania, które wspiera krytyczny zmysł aktualności, przechodzą w systematyczne naukowe badania, ugruntowane $\mathrm{w}$ świadomości użytych metod. Podejście poetologiczne powiązane $\mathrm{z}$ historią form i genologią jest szczególne cenne. Za najlepszy przykład posłużyć może rozprawa Agnieszki Kluby, w której spotykają się dyskusja o aparacie terminologicznym, 
historia recepcji ograniczona do rozumienia próz poetyckich Zbigniewa Herberta oraz próba nowego spojrzenia na utwory reprezentujące ten gatunek ${ }^{35}$.

Często refleksja nad pisarstwem autora Rovigo wraz z procedurami porównywania wykracza poza terytorium literackie, przenosząc się na grunt sztuki i filozofii. W najnowszej refleksji nad twórczością Zbigniewa Herberta przeważają rozważania o wielorakich inspiracjach filozoficznych - od presokratyków, poprzez wątki nietzscheańskie do myśli fenomenologicznej - a także o poszukiwaniu sacrum, rekonstrukcji dialogu ze sztuką, o założeniach estetycznych, koncepcji Herbertowskiej poezji oraz poetyce tekstów. Do owego wyliczenia dołączyłbym orientację kulturową, czyli usytuowanie tej twórczości wobec wytwarzanych społecznie dyskursów, ujawnienie roli ciała i rzeczy, namysł nad podmiotowością. Podjęta też została refleksja nad oddziaływaniem pisarstwa Herberta na artystów słowa następnych pokoleń i kontynuowane są badania nad powstawaniem poszczególnych tekstów. Dla porządku wymienić należy prace z lat ostatnich, chociaż na bliższe ich omówienie nie ma już w tym szkicu miejsca. Oto niepełny wybór: Joanny Adamowskiej Róźewicz i Herbert. Aksjologiczne aspekty twórczości (2012), Artura Grabowskiego Herbert-Hermes. Konteksty nowoczesności w esejach, dramatach i wierszach Zbigniewa Herberta (2013), Magdaleny Śniedziewskiej Siedemnastowieczne malarstwo holenderskie w literaturze polskiej po roku 1918 (2014), Mirosława Dzienia Motywy eschatologiczne w poezji Zbigniewa Herberta. Studium analityczno-interpretacyjne (t. 1-2, 2014), Katarzyny Wyszyńskiej Sukcesorzy Pana Cogito (2016), Wojciecha Ligęzy Bez rutyny. O poezji Wistawy Szymborskiej i Zbigniewa Herberta (2016), Piotra Siemaszki, Wehikut poezji i cnoty. Myśl o pięknie w twórczości Zbigniewa Herberta (2016), Romana Bobryka Koncept poezji i poety w wierszach Zbigniewa Herberta (2017), Jana Księżyka Znaczenie ekfrazy dla poetyki narracji eseistycznej: formy ocalania wartości doświadczenia piękna w eseistyce Zbigniewa Herberta (2017), Radosława Siomy Krzesto i zmięta serweta. Szkice o twórczości Zbigniewa Herberta (2017), a także tomy zbiorowe ${ }^{36}$.

W dotychczasowych opisach nie zajmowałem się interpretacjami wierszy Zbigniewa Herberta. Wielość odczytań pojedynczych utworów wskazuje na to, iż z jednej strony ranga wyzwań jest wysoka, a z drugiej strony bogactwo znaczeń poetyckich partytur zachęca do podejmowania kolejnych prób. W procesie nieustannego komentowania interpretacje podążają w głąb semantyki tekstów. W długotrwałej recepcji rozwijają się szczegółowe egzegezy. Popularne i sławne utwory poetyckie Herberta mają już swoje odrębne mikrohistorie lektury

35 A. Kluba, Zbigniew Herbert [w:] tejże, Poemat proza w Polsce, Warszawa-Toruń 2014, s. $477-500$.

${ }^{36}$ Zob. między innymi: Bór nici. Wątki klasyczne i romantyczne $w$ twórczości Zbigniewa Herberta, red. M. Mikołajczak, Kraków 2011; Między nami a świattem. Bóg i świat w twórczości Zbigniewa Herberta, red. G. Halkiewicz-Sojak, R. Sioma, Toruń-Kraków 2012; Nagła wyspa..., dz. cyt.; Pracownia Herberta. Studia nad procesem tekstotwórczym, red. M. Antoniuk, Kraków 2017. 
krytycznej i naukowej. W pamięci znawców i czytelników utrwaliło się wiele interpretacji, jednak zgromadzenie dowodów zajęłoby dobrych parę stron, chociaż istnieją odczytania klasyczne - rozbudowane do rozmiarów rozpraw, przedrukowywane $w$ antologiach, często cytowane $e^{37}$. Pojedyncze utwory poetyckie Herberta pozwalają wejrzeć w artystyczno-ideową całość, ale również przywołać szerokie konteksty kultury, w których lokują się odczytywane wypowiedzi poetyckie.

Przyrostowi końca nie ma: interpretacje poszczególnych wierszy mogłyby się ułożyć w antologie. Jako wyraziste przykłady można podać Tren Fortynbrasa ${ }^{38}$, Przestanie Pana Cogito ${ }^{39}$, Elegię na odejście pióra atramentu lampy ${ }^{40}$.

${ }^{37}$ Na przykład: J. Sławiński, Tren Fortynbrasa [w:] Poznawanie Herberta, dz. cyt., s. 359375; S. Barańczak, Cnota, nadzieja, ironia (Zbigniew Herbert: Pan Cogito o cnocie), w: tegoż, Tablica z Macondo. Osiemnaście prób wyttumaczenia, po co i dlaczego siępisze, Londyn 1990, s. 71-85; M. Stala, W cieniu dębów. Nie tylko o jednym wierszu Zbigniewa Herberta; J. Łukasiewicz, Elegia na odejście pióra atramentu lampy [te trzy teksty] [w:] Poznawanie Herberta 2, dz. cyt., s. 381-398, 436-443, 444-456; R. Nycz, „Niepewna jasnośc”” tekstu i „wiernośc” interpretacji. Wokót wiersza Zbigniewa Herberta „Pan Cogito opowiada o kuszeniu Spinozy”; D. Pawelec, „Bądź wierny Idż” [Przestanie Pana Cogito]; [te dwa teksty] [w:] Niepewna jasność tekstu..., dz. cyt., s. 33-55, 75-111.

${ }^{38}$ Między innymi prace: S. Dąbrowski, Hamlet i Fortynbras (Między literaturą a rzeczywistościa), „Tygodnik Powszechny” 1971, nr 8; A. Kamieńska, Okrucieństwo mitu, [w:] tejże, Od Leśmiana. Najpiękniejsze wiersze polskie, Warszawa 1974; K. Wyka, Tren Fortynbrasa [w:] tegoż, Rzecz wyobraźni, Warszawa 1977 (wyd. 2); J. Sławiński, Tren Fortynbrasa [w:] Poznawanie Herberta; J. Trznadel, Kamieniowanie mądrości [w:] tegoż, Ptomień obdarzony rozumem. Poezja w poezji i proza poezja. Eseje, Warszawa 1978; D. Opacka-Walasek, „Tren Fortynbrasa” [w:] tejże, Czytając Herberta, Katowice 2001; R. Sioma, Jeszcze raz o „Trenie Fortynbrasa” [w:] Opis wiersza. Analizy i interpretacje liryki polskiej, red. R. Sioma, Toruń 2002, przedruk [w:] R. Sioma, Krzesto i zmięta serweta. Szkice o twórczości Zbigniewa Herberta, Kraków 2017, s. 11-35; M. Mikołajczak, Czytać, "Tren Fortynbrasa" do końca, [w:] tejże, W cieniu heksametru. Interpretacje wierszy Zbigniewa Herberta, Zielona Góra 2004; J.M. Ruszar, Racje Fortynbrasa, racje Hamleta [w:] tegoż, Stróż brata swego. Zasada odpowiedzialności w liryce Zbigniewa Herberta, Lublin 2004.

39 Znów wykaz jest niepełny: A. Kowalczyk, Ztote runo nicości. „Przestanie Pana Cogito”próba lektury, „Tygodnik Powszechny” 1983, nr 11; J. Łukasiewicz, „Przestanie Pana Cogito” [w:] tegoż, Poezja Zbigniewa Herberta, dz. cyt., s. 75-84; A. Nawarecki, Trzy ostatnie stowa Pana Cogito. O wierszu Zbigniewa Herberta „Przestanie Pana Cogito” [w:] Kanonada. Interpretacje wierszy polskich (1939-1989), red. A. Nawarecki, D. Pawelec, Katowice 1999; J. Bigaj, Za przestaniem Herberta nie pójdę... [w:] Herbert. Poetyka, wartości i konteksty, dz. cyt., s. 165172; K. Kłosiński, Poezja zaimków. O „Przestaniu Pana Cogito” Zbigniewa Herberta [w:] Liryka polska XX wieku. Analizy i interpretacje. Seria trzecia, red. W. Wójcik, J. Kisielowa, Katowice 2005; K. Biedrzycki, ...Bez zmartwychpowstania [w:] tegoż, Wariacje metafizyczne. Szkice i recenzje o poezji, prozie i filmie, Kraków 2007, s. 93-103; D. Pawelec, Bądź wierny Idź [w:] Niepewna jasność tekstu..., dz. cyt., s. 77-111; „Ztote runo nicości”. O „Przestaniu Pana Cogito” [...] dyskutują Stefan Chwin, Tadeusz Dąbrowski, Andrzej Franaszek, Ryszard Krynicki, Marian Stala i Piotr Śliwiński, ,Tygodnik Powszechny” 2008, nr 44, dodatek Herbert, s. 406.

${ }^{40}$ Na przykład: J. Łukasiewicz, „Elegia na odejście pióra atramentu lampy” [w:] tegoż, Poezja Zbigniewa Herberta, dz. cyt.; W. Ligęza, Elegie Zbigniewa Herberta [w:] Twórczość Zbigniewa Herberta..., dz. cyt.; A. Legeżyńska, Gest pożegnania, D. Pawelec, Elegia [te dwa teksty] [w:] Niepewna jasnośc tekstu..., dz. cyt.; W. Kudyba, Ostatnie rzeczy Herberta. Troska w „Elegii na odejście pióra atramentu lampy" [w:] Gąszcz srebrnych liści. Interpretacje wierszy Zbigniewa Herberta, red. J.M. Ruszar, Kraków 2015, s. 171-182. 
Podobnie inne utwory poetyckie Herberta mają już swoje odrębne mikrohistorie czytania. Wymieńmy wiersze Do Marka Aurelego, Stotek, Wawel, Nike, która się waha, Las Ardenski, Arijon, Chrzest, U wrót doliny, Przypowieśc, Balkony, Pokój umeblowany, Pieśn o bębnie, Substancja, Apollo i Marsjasz, Powrót prokonsula, Studium przedmiotu, Kamyk, Dlaczego klasycy, Prolog, Pan Cogito rozmyśla o cierpieniu, Historia Minotaura, Pan Cogito opowiada o kuszeniu Spinozy, Pan Cogito szuka rady, Pan Cogito o postawie wyprostowanej, Ze szczytu schodów, Fotografia, Dawni Mistrzowie, Modlitwa Pana Cogito - podróżnika, Do Ryszarda Krynickiego - list, Potwór Pana Cogito, Pan Cogito - zapiski z martwego domu, Raport z oblężonego Miasta, Dęby, Mate serce, Czarnofigurowe dzieto Eksekiasa, Rovigo, cykl Brewiarzy, Pan Cogito. Aktualna pozycja duszy, Czutość, Tkanina. Istnieje przekonanie, że tylko szczegółowe prace interpretacyjne mogą ukazać jeszcze jakiś nowy aspekt pisarstwa Herberta. Dlatego biblioteka interpretacji wciąż się poszerza. Każdy wiersz i niemal każdy wers nie powinien umknąć analitycznemu spojrzeniu. Często znajdujące się dotąd na drugim planie utwory poetyckie w kolejnych próbach lektury stają się przedmiotem osobnych studiów i szkiców.

Przyrasta również liczba zbiorów interpretacji ukazujących szerokie spektrum stylów, tematów, przesłań filozoficznych ${ }^{41}$. Bywa tak, że pojedynczy utwór poetycki, umieszczany w wielu kontekstach, jest traktowany jak synekdocha całości. Zatem trwa proces wypełniania miejsc pustych. I jeszcze: zmienia się Herbertowski kanon, gdyż dokonuje się przesunięć w hierarchii ważności wierszy ze względu na artyzm i przesłania. Zabrzmi to jak truizm, ale przypomnieć należy, iż interpretacje kompletne i definitywne mogą istnieć jedynie jako projekcja humanistycznych bytów idealnych. Natomiast praktyka lektury zawsze pozostawia jakieś pole znaczeń do literaturoznawczego zagospodarowania.

Poesia docta prowokuje do porównań, zachęca do rekonstrukcji wielopoziomowych odsyłaczy do literatury, sztuk pięknych, filozofii oraz rozmaitych dziedzin nauki. Narracje literaturoznawcze o twórczości Herberta często u swoich podstaw umieszczają komentarze erudycyjne. Odczytywanie to zatem wyjawienie inspiracji, identyfikowanie źródeł, powrót, jeśli można tak powiedzieć, do przedtekstowych postaci poszukiwań poety. Oczywiście na rozpoznawaniu aluzji, deszyfrowaniu centonów, rozpoznawaniu cytatów i quasi-cytatów procedura interpretacji się nie kończy. Istotne są bowiem pytania, w jaki sposób magazyn topiczny służy poetyckiej nowości oraz na czym polega oryginalność Zbigniewa Herberta w posługiwaniu się znakami kultury.

Spokrewniona z takim podejściem jest komparatystyka około-Herbertowa. Pisarstwo autora Martwej natury $z$ wędzidtem, lokując się w centrum

${ }^{41}$ Zob. między innymi: Dlaczego Herbert. Wiersze, komentarze, interpretacje, red. M. Woźniak-Łabieniec, J. Wiśniewski, Łódź 2004; J. Łukasiewicz, Poezja Zbigniewa Herberta, dz. cyt.; D. Opacka-Walasek, Czytając Herberta, dz. cyt.; Niepewna jasność tekstu..., dz. cyt. [cz. 1]; Gąszcz srebrnych liści..., dz. cyt.; Zemsta ręki śmiertelnej. Interpretacje wierszy poetów XX wieku, red. J.M. Ruszar, D. Siwor, Kraków 2017 [pierwsza sekwencja tekstów poświęcona jest wierszom Herberta]. 
dyskutowanych idei czasu aktualnego, osadzone w wartościach uniwersalnych, dostarczające wzorów przeżywania nowoczesnego i ponowoczesnego świata, sprzyja zestawieniom z wielkimi i największymi postaciami literatury XIX i XX wieku. Dlatego badacze porównują wypowiedzi poetyckie Herberta z utworami Josepha Conrada, Friedricha Hölderlina, Rainera Marii Rilkego, T.S. Eliota ${ }^{42}$, Konstandinosa Kawafisa, W.H. Audena, Sylwii Plath, Paula Celana, Josifa Brodskiego, Seamusa Heaney'a, Cypriana Kamila Norwida, Jerzego Lieberta, poetów wojennych (Tadeusza Gajcego, Krzysztofa Kamila Baczyńskiego, Zdzisława Stroińskiego, Tadeusza Borowskiego), Tadeusza Różewicza, Witolda Wirpszy, Wisławy Szymborskiej, Stanisława Grochowiaka, Jarosława Marka Rymkiewicza, Mirona Białoszewskiego, Stanisława Barańczaka czy Adama Zagajewskiego. Eseistyka natomiast zestawiana była z tekstami Józefa Wittlina, Gustawa Herlinga-Grudzińskiego, Józefa Czapskiego, Konstantego Jeleńskiego, Andrzeja Kijowskiego. Osobne miejsce zajmują paralele, dialogi i biograficzne relacje Herberta z Miłoszem obfitujące w sporą ilość literaturoznawczych opisów ${ }^{43}$. Obszerną bibliografię posiada również dialog poety z jego mistrzem filozoficznym - Henrykiem Elzenbergiem.

Oczywiście każda próba porządkowania nieuchronnie pociąga za sobą uproszczenia i przeoczenia. W tym szkicu próby referowania w jakiejś mierze zdominowały wartościowanie, a przynajmniej znacznie ograniczyły tego rodzaju sądy. Ponadto opis różnorakich przyswojeń krytycznych wcale nie stwarza sytuacji luksusowej, gdyż wypowiedzi o sposobach czytania twórczości Zbigniewa Herberta lokują się w długim ciągu świadectw lektury. Konieczne jest zatem przeskoczenie na poziom metarefleksji, namysł nad „recepcją recepcji”.

${ }^{42}$ Rilke i Eliot, wymienieni w często przywoływanym wierszu Do Ryszarda Krynickiego list (z tomu Raport z oblężonego Miasta), mają dla Herberta największe znaczenie. Zob. K. Kuczyńska-Koschany, Rilke poetów polskich, Toruń 2017, s. 278 i n. (wyd. 2). Także: P. Łuszczykiewicz, Rilke, Eliot, Herbert..., „Dialog” 1998, nr 12, s. 143-144.

${ }^{43}$ Zob. A. Fiut, Ukryty dialog [w:] tegoż, W stronę Mitosza, Kraków 2003, s. 225-247, przedruk [w:] Niepewna jasność tekstu..., dz. cyt., s. 171-190; tenże, Męczeństwo i ziemskie rozkosze. O poetyckiej galerii Mitosza i Herberta [w:] Zmyst wzroku, zmyst sztuki. Prywatna historia sztuki Zbigniewa Herberta, cz. 2, Lublin 2006, s. 11-29; B. Carpenter, Czestaw Mitosz i Zbigniew Herbert - poeta wygnania [w:] Literatura polska na obczyźnie, red. J. Bujnowski, Londyn 1985, s. 176-192; D. Opacka-Walasek, „... pozostać wiernym niepewnej jasności”. Wybrane problemy poezji Zbigniewa Herberta, Katowice 1996, s. 54-59, 68-72; J. Tomkowski, Herbert contra Mitosz [w:] tegoż, Dwadzieścia lat z literatura 1977-1996, Warszawa 1998; A. Biskupski, Mitosz - Herbert. Poznanie dobra i zta [w:] Herbert i znaki czasu..., dz. cyt.; S. Stabro, Poetycka idea narodu w „Substancji” Zbigniewa Herberta i w „Narodzie” Czestawa Mitosza [w:] Portret z początku wieku. Twórczość Zbigniewa Herberta - kontynuacje i rewizje, red. W. Ligęza przy współudz. M. Cichej, Lublin 2005; Z. Zarębianka, Spór o wartości? Herbert-Mitosz [w:] Dialog i spór. Zbigniew Herbert a inni poeci i eseisci, red. J.M. Ruszar, D. Koman, Lublin 2006, s. 108-117, przedruk [w:] tejże, Wtajemniczenia (w) Mitosza, Kraków 2014, s. 59-70; D. Zawistowska-Toczek, „Pojedynek wieszczów”. Konflikt z Czestawem Mitoszem [w:] tejże, Stary poeta..., dz. cyt., s. 175-202, ostatnio: R. Sioma, „Źródto nieba na ziemi”. Metafizyka zachwytu: Mitosz - Herbert (rekonesans) [w:] Zemsta ręki śmiertelnej..., dz. cyt., s. 99-112. 
W przybliżanych w tym szkicu praktykach badawczych oprócz scalania i porządkowania pojawia się ruch wstecz: rozkurz idei, powtórzenia, banalizacja spostrzeżeń, nadmiar komentarzy niekoniecznych, przyczynkarskich.

Tłumne czytanie wcale nie oznacza czytania uważnego. Bywa tak, że kolejne interpretacje są gorsze od poprzednich. Jest to produkt uboczny standaryzacji nauki i przy tym pędu za modnymi metodami i językami interpretacji. Ponadto recepcja to dzieje rozpoznawania i zapominania, trwa bowiem nieustannie wyścig $\operatorname{prac}^{44}$. Nie podzielam diagnozy, iż „czas dojrzałej recepcji Herbertowego dzieła dopiero przed nami”"45. Raczej byłbym zwolennikiem tezy, że zamiast mnożenia kolejnych egzegez, warto by przeczytać dokładnie bibliotekę tekstów o twórczości Herberta, ze szczególnym uwzględnieniem prac klasycznych - kanonicznych.

Autor Pana Cogito postrzegany był jako poeta kultury, znawca zagadnień malarstwa, artysta moralnego sprzeciwu, który piętnował zło komunizmu, pisarz historiozoficznej, egzystencjalnej i metafizycznej refleksji, również człowiek postaw radykalnych, „który w każdych okolicznościach dochowywał wierności swoim ambicjom narodowym, politycznym, artystycznym i filozoficznym" ${ }^{46}$. Zbigniew Herbert to moralista broniący bezcennych racji przegranej jednostki, ironista - rozprawiający o fałszywych wagach i miarach, jakimi ze strachu, i konformizmu chętnie się posługujemy. Wreszcie Herbert jawił się swym odbiorcom jako poeta cierpienia, a także poeta refleksji o odchodzeniu i śmierci.

Jednocześnie warto pamiętać o przestrodze Adama Zagajewskiego, w której zawiera się też pośrednio myśl o trudno wyczerpywalnych możliwościach odnowionego odbioru:

W doskonałych nieraz książkach i szkicach poszukiwano zasady poezji Herberta: neoklasycyzm, uciekinier z utopii, poeta wierności, głos cierpienia. Jego twórczość dziwnie jest odporna na krytyczne dociekania; a zwłaszcza opiera się próbie znalezienia $\mathrm{w}$ niej jednego centralnego punktu ${ }^{47}$.

Jak się wydaje, kolejnym badaczom nie zagraża nuda, gdyż - pomimo rozlicznych prób przybliżenia twórczości Herberta - nie wszystkie idee zostały odczytane i „doczytane”. Ten pisarz antynomii oraz paradoksów wciąż będzie zachęcać do ponownych lektur jego dzieł.

${ }_{44}$ Piszę o tym dokładniej w tekście Sukces, przesyt, znaki obecności [w:] Herbert, dodatek do „Kwartalnika Artystycznego” 2008, nr 2, s. 40-45.

${ }^{45}$ A. Grabowski, J. Kopciński, Herbert na językach - wyznanie wstępne [w:] Herbert na językach..., dz. cyt., s. 8.

46 G. Herling-Grudziński, Byt wierny [w:] Wierność..., dz. cyt., s. 252.

47 A. Zagajewski, Początek wspominania, [w:] Wierność..., dz. cyt., s. 296-297, pierwodruk: „Zeszyty Literackie” 1999, nr 4. 


\section{Bibliografia}

Adamiec M. „...Pomnik trochę niezupetny...”. Rzecz o apokryfach i poezji Zbigniewa Herberta, Gdańsk 1996.

Adamowska J., Różewicz i Herbert. Aksjologiczne aspekty twórczości, Kraków 2012.

Antoniuk M., Otwieranie gtosu. Studium o wczesnej twórczości Zbigniewa Herberta (do 1957 roku), Kraków 2009.

Archiwum Zbigniewa Herberta. Inwentarz, oprac. H. Citko, Warszawa 2008.

Balcerzan E., Arkadyjczyk w oblężonym mieście (O poezji Zbigniewa Herberta), „Twórczość” 1986, nr 10.

Barańczak S., Uciekinier z Utopii. O poezji Zbigniewa Herberta, Londyn 1984.

Biedrzycki K., ...Bez zmartwychpowstania [w:] tegoż, Wariacje metafizyczne. Szkice i recenzje o poezji, prozie i filmie, Kraków 2007.

Bobryk R., Koncept poezji i poety w wierszach Zbigniewa Herberta, Siedlce 2017. Bór nici. Wątki klasyczne i romantyczne w twórczości Zbigniewa Herberta, red. M. Mikołajczak, Kraków 2011.

Carpenter B., Czestaw Mitosz i Zbigniew Herbert - poeta wygnania [w:] Literatura polska na obczyźnie, red. J. Bujnowski, Londyn 1985.

Czytanie Herberta, red. P. Czapliński, P. Śliwiński, Poznań 1995.

Czutość dla Minotaura. Metafizyka i mitość konkretu, red. J.M. Ruszar, M. Cicha, Lublin 2005.

Dąbrowski S., Hamlet i Fortynbras (Między literatura a rzeczywistościa), „Tygodnik Powszechny" 1971, nr 8.

Dialog i spór. Zbigniew Herbert a inni poeci i eseiści, red. J.M. Ruszar, D. Koman, Lublin 2006.

Dlaczego Herbert. Wiersze, komentarze, interpretacje, red. M. Woźniak-Łabieniec, J. Wiśniewski, Łódź 2004.

Dudek J., Granice wyobraźni, granice stowa. Studia z literatury porównawczej XX wieku, Kraków 2008.

Dzień M., Motywy eschatologiczne w poezji Zbigniewa Herberta. Studium analityczno-interpretacyjne, t. 1-2, Bielsko Biała 2014.

Fiut A., Jezyk wiary i niewiary [w:] tegoż, Pytanie o tożsamość, Kraków 1995.

Fiut A., Ukryty dialog [w:] tegoż, W stronę Mitosza, Kraków 2003.

Franaszek A., Ciemne źródto (o twórczości Zbigniewa Herberta), Londyn 1998.

Gąszz srebrnych liści. Interpretacje wierszy Zbigniewa Herberta, red. J.M. Ruszar, Kraków 2015.

Grabowski A., Herbert-Hermes. Konteksty nowoczesności w esejach, dramatach i wierszach Zbigniewa Herberta, Kraków 2013.

Herbert i znaki czasu. Colloquia Herbertiana, red. E. Feliksiak, M. Leś, E. Sidoruk, t. 1: Białystok 2001, t. 2: Białystok 2002.

Herbert na jezykach. Wspótczesna recepcja twórczości Zbigniewa Herberta w Polsce i na świecie, red. A. Grabowski, J. Kopciński, J. Snopek, Warszawa 2010.

Herbert (nie)oswojony, red. W. Browarny, J. Orska, A. Poprawa, Wrocław 2008. 
Herbert nieznany. Rozmowy, oprac. H. Citko, Warszawa 2008.

Herbert. Poetyka, wartości i konteksty, red. E. Czaplejewicz, W. Sadowski, Warszawa 2002.

Herbert Środkowoeuropejczyk. Twórczośc Zbigniewa Herberta w kontekstach i kontaktach środkowoeuropejskich, red. K. Krasuski, Katowice 2011.

Herbert Z., Gtosy Herberta, oprac. B. Toruńczyk, Warszawa 2008.

Herbert Z., Labirynt nad morzem, Warszawa 2000.

Herbert Z., „Mistrz z Delft” i inne utwory odnalezione, oprac. B. Toruńczyk, współpraca H. Citko, Warszawa 2008.

Herbert Z., Węzet gordyjski oraz inne pisma rozproszone 1948-1998, oprac. P. Kądziela, Warszawa 2001.

Herbert Z., Wiersze zebrane, oprac. R. Krynicki, Kraków 2008.

Herbert Z., Barańczak S., Korespondencja, red., oprac. B. Toruńczyk, Warszawa 2005.

Hryniewicz K. Cogito i dubito. Dyskurs estetyczny w poezji Zbigniewa Herberta i Tadeusza Różewicza, Kraków 2014.

Kaliszewski A., Nostalgia stylu. Neoklasycyzm liryki polskiej XX wieku w krytyce, badaniach i poetykach immanentnych ( $w$ kontekście tradycji poetologicznej klasycyzmu), Kraków 2007.

Kamieńska A., Niewierny Tomasz i świat, „Twórczość” 1957, nr 10-11.

Kamieńska A., Okrucieństwo mitu [w:] tejże, Od Leśmiana. Najpiękniejsze wiersze polskie, Warszawa 1974.

Kądziela P., Twórczośc Zbigniewa Herberta. Monografia bibliograficzna, t. 1-2, Warszawa 2009.

Kluba A., Zbigniew Herbert [w:] tejże, Poemat proza w Polsce, WarszawaToruń 2014.

Kłosiński K., Poezja zaimków. O „Przestaniu Pana Cogito” Zbigniewa Herberta [w:] Liryka polska XX wieku. Analizy i interpretacje. Seria trzecia, red. W. Wójcik, J. Kisielowa, Katowice 2005.

Kornhauser J., Uśmiech Sfinksa, Kraków 2001.

Kowalczyk A., Ztote runo nicości. „Przestanie Pana Cogito”- próba lektury, „Tygodnik Powszechny” 1983, nr 11.

Kramkowska-Dąbrowska A., Gabinet luster. Śmiech w twórczości Zbigniewa Herberta, Warszawa 2015.

Kuczyńska-Koschany K., Rilke poetów polskich, Toruń 2017.

Kwiatkowski J., Klerk mężny, „Życie Literackie” 1957, nr 40.

Ligęza W., Bez rutyny. O poezji Wistawy Szymborskiej i Zbigniewa Herberta, Kraków 2016.

Ligęza W., Sukces, przesyt, znaki obecności [w:] Herbert, dodatek do „Kwartalnika Artystycznego" 2008, nr 2.

Liryka i fenomenologia. Zbigniew Herbert i Tadeusz Różewicz w kręgu myśli Ingardenowskiej, red. J.M. Ruszar, D. Siwor, Kraków 2016.

Łukasiewicz J., Herbert, Wrocław 2001. 
Łukasiewicz J., Poezja Zbigniewa Herberta, Warszawa 1995.

Łuszczykiewicz P., Rilke, Eliot, Herbert..., „Dialog” 1998, nr 12.

Matuszewski R., Wiersze piękne i rozumne [w:] tegoż, Doświadczenia i mity, Warszawa 1964.

Mazurkiewicz-Szczyszek A., W asyście jakich dzwonów. Obrazy miasta w twórczości Zbigniewa Herberta, Lublin 2008.

Michnik A., Potęga smaku [w:] tegoż, $Z$ dziejów honoru w Polsce. Wypisy więzienne, Paryż 1985.

Między nami a świattem. Bóg i świat w twórczości Zbigniewa Herberta, red. G. Halkiewicz-Sojak, J.M. Ruszar, R. Sioma, Toruń-Kraków 2012.

Mikołajczak M., Pomiędzy końcem i apokalipsą. O wyobraźni poetyckiej Zbigniewa Herberta, Wrocław 2007.

Mikołajczak M., Światy z marzenia. Echa romantyczne w poezji Zbigniewa Herberta, Zielona Góra-Kraków 2013.

Mikołajczak M., „W cieniu heksametru”. Interpretacje wierszy Zbigniewa Herberta, Zielona Góra 2004.

Nagta wyspa. Studia i szkice o pisarstwie Zbigniewa Herberta, red. P. Próchniak, Lublin 2015.

Nasiłowska A., Zbigniew Herbert: Pan Cogito ma ktopoty [w:] Sporne postaci polskiej literatury wspótczesnej. Kontynuacje, red. A. Brodzka, L. Burska, Warszawa 1996.

Nawarecki A., Trzy ostatnie stowa Pana Cogito. O wierszu Zbigniewa Herberta „Przestanie Pana Cogito" [w:] Kanonada. Interpretacje wierszy polskich (1939-1989), red. A. Nawarecki, D. Pawelec, Katowice 1999.

Niepewna jasność tekstu. Szkice o twórczości Zbigniewa Herberta 1998-2008, red. J.M. Ruszar, Kraków 2009.

Opacka-Walasek D., Czytając Herberta, Katowice 2001.

Opacka-Walasek D., „...pozostać wiernym niepewnej jasności”. Wybrane problemy poezji Zbigniewa Herberta, Katowice 1996.

Panas P., Herbertowe „ars moriendi” [w:] Wyraz wytuskany z piersi. Szkice o twórczości Zbigniewa Herberta, red. B. Gautier, D. Knysz-Tomaszewska, J.M. Ruszar, M. Zieliński, Lublin 2006.

Pietrych K., Spotkanie drugie: Zbigniew Herbert [w:] tejże, Co poezji po bólu. Empatyczne przestrzenie lektury, Łódź 2009.

Pojęcia kietkujące z rzeczy. Filozoficzne inspiracje twórczości Zbigniewa Herberta, red. J.M. Ruszar, Kraków 2010.

Portret z początku wieku. Twórczość Zbigniewa Herberta - kontynuacje i rewizje, red. W. Ligęza przy współudz. M. Cichej, Lublin 2005.

Poznawanie Herberta, wybór i wstęp A. Franaszek, Kraków 1998.

Poznawanie Herberta 2, red. A. Franaszek, Kraków 2000.

Pracownia Herberta. Studia nad procesem tekstotwórczym, red. M. Antoniuk, Kraków 2017. Ruszar J.M., Stońce republiki. Cywilizacja rzymska w twórczości Zbigniewa Herberta, Kraków 2014. 
Ruszar J.M., Stróż brata swego. Zasada odpowiedzialności w liryce Zbigniewa Herberta, Lublin 2004.

Ruszar J.M., Wytarty profil rzymskich monet. Ekonomia jako temat literacki w twórczości Zbigniewa Herberta, Kraków 2016.

Siemaszko P., Wehikut pasji i cnoty. Myśl o pięknie w twórczości Zbigniewa Herberta, Bydgoszcz 2016.

Sioma R., Krzesto i zmięta serweta. Szkice o twórczości Zbigniewa Herberta, Kraków 2017.

Śniedziewska M., Wierność rzeczywistości. Zbigniew Herbert o postawie wobec świata i problemach jego reprezentacji, Kraków 2013.

Tomkowski J., Herbert contra Mitosz [w:] tegoż, Dwadzieścia lat z literatura 19771996, Warszawa 1998.

Toruńczyk B., Dukt pisma, dukt pamięci, „Zeszyty Literackie” 1999, nr 4.

Trznadel J., Kamieniowanie madrości [w:] tegoż, Ptomień obdarzony rozumem. Poezja w poezji i proza poezja. Eseje, Warszawa 1978.

Twórczość Zbigniewa Herberta, red. M. Woźniak-Łabieniec, J. Wiśniewski, Kraków 2001.

Upór i trwanie. Wspomnienia o Zbigniewie Herbercie, red. K. Szczypka, Wrocław 2000.

Urbankowski B., Poeta, czyli cztowiek zwielokrotniony. Szkice o Zbigniewie Herbercie, Radom 2004.

Wierność. Wspomnienia o Zbigniewie Herbercie, wybór i oprac. A. Romaniuk, Warszawa 2014.

Wyka K., Sktadniki świetlnej struny, „Życie Literackie” 1956, nr 42.

Wyka K., Tren Fortynbrasa [w:] tegoż, Rzecz wyobraźni, Warszawa 1977.

Wyka M., Niecierpliwość krytyki. Recenzje i szkice z lat 1961-2005, Kraków 2006.

Zagajewski A., Wiersze Herberta, które lubię najbardziej [w:] tegoż, Poezja dla początkujących, Warszawa 2017.

Zawistowska-Toczek D., Stary poeta. „Ars moriendi” w późnej twórczości Zbigniewa Herberta, Lublin 2008.

Zemsta ręki śmiertelnej. Interpretacje wierszy poetów XX wieku, red. J.M. Ruszar, D. Siwor, Kraków 2017.

Zimand R., Ogród i barbarzyńca [w:] tegoż, Czas normalizacji. Szkice czwarte, Londyn 1989.

„Ztote runo nicości”. O „Przestaniu Pana Cogito” [...] dyskutuja Stefan Chwin, Tadeusz Dąbrowski, Andrzej Franaszek, Ryszard Krynicki, Marian Stala i Piotr Śliwinsski, „Tygodnik Powszechny” 2008, nr 44, dodatek Herbert.

Zmyst wzroku, zmyst sztuki. Prywatna historia sztuki Zbigniewa Herberta, cz. 2, red. J.M. Ruszar, Lublin 2006. 